\title{
Emergence of New Woman in Augusta
}

\section{Gregory's Grania}

\section{Lekha Nath Dhakal}

\begin{abstract}
Associate Professor, Department of English, Tribhuvan University, Nepal Commerce Campus, Kathmandu, Nepal Email: lekhanathdhakal50@gmail.com
\end{abstract}

\begin{abstract}
This paper makes an attempt to discuss the idea of new woman in Augusta Gregory's play, Grania by the application of the idea of different critics about new woman. Grania is one of the representatives of revolutionary play, which focuses on female's individual desire rather than her submissive role. For Grania, the protagonists of the drama, gone are the days when women cries for their lost husband and lament upon being widow. She focuses that women can also remarry if they wish. By getting married with Finn after the death of Diarmuid, she proves her free will and her desire for power from every sides of life. She never surrendered in front of patriarchy, though many times it compelled her to do so. It is not the victory of only Grania but it is the victory of women's movement. Individual freedom is the motto of her life and that individual freedom becomes collective freedom for all women. Grania's courage, wisdom proves that she is a new woman emerged in the New Ireland.
\end{abstract}

Keywords-Freedom, New Woman, Patriarchy, Revolutionary.

This paper explores the emergence of new woman in Augusta Gregory's Grania by analyzing what is a new woman? Whether Grania is a new woman or not? If so, how does she emerge in the play? What is her role in the play? How does she react against patriarchy? What is her role to make a new nation i.e. New Ireland? Does she focus the issues of nationalism? What is a nation for her? Does her concept of nation different from other character? Based upon these questions, I am trying to analyze whether Grania is a new woman or not? Before analyzing the text, it is imperative to introduce the concept of new woman. During the period of late nineteenth and early twentieth century, there was drastic change in women's life. At that time, women got success to break the chain constructed by patriarchy. So, they blurred the boundaries between home and outside. Cathy Leeney has pointed the emergence of new woman in theatre during the period of late nineteenth and early twentieth century in her essay, "The New Woman in a New Ireland?: Grania After Naturalism":

The re-figuring of what it was to be a woman took place against a backdrop of anxious misogyny, characterized by fearful representations of female power. In theatre, writers associated with the naturalist movement commonly placed representations of the female at the centre of their dramas: Therese Raquin, Nora Helmer, Hedda Gabler, Miss Julie, Mrs Warren. Concerned with women's moral, emotional, and financial independence, and with their destiny as individuals rather than as mothers or wives, these plays dramatized situations arising from the then current oppressive patriarchal binaries of female identity: the angel in the house, the monstrous whore outside it. (157) Cathy Leeney tries to show how the concept of woman has been blurred in the theatre. Her focus is to locate central role played by women. Before late nineteenth century, women did not get major role in the play, there was not any focus on women's individual desire but in late nineteenth and early twentieth century's plays focuses on women's individual desire rather than their submissive role. She pointed out that those plays got success to break the female identity i.e. the angel in the house and the monstrous whore outside it which is the symbol of emergence of new woman. Likewise another critic Lynn Dumenil has clarified new woman in her essay, 'The New Woman and the Politics of the 1920s':

Perceptions of a new woman emerged as early as the 1890 s.The term itself referred to women's increased college attendance modest entry into the professions, and to their new athleticism and rejection of bulky, restrictive Victorian garments. It also encompassed the way in which late nineteenth century middle- class women had begun to shed traditional notions that their place was exclusively in the home. They were pushing out the boundaries of their traditional sphere and entering the political arena. Through their voluntary associations, these women had become political actors, lobbying for progressive reform legislation such as factory and child labour laws, prohibition, and urban reforms. (22) 
Dumenil focuses that though new woman emerged in 1890s, it also encompassed the way in which latenineteenth-century middle class women had begun to shed traditional notions that their place was exclusively in the home. She tries to show that new woman emerged by breaking the boundaries between home and outsides. Rejection of traditional boundaries and their role as a political actors are the example of new woman for Dumenil.

Augusta Gregory's Grania is also one of the representatives of revolutionary play which focuses female's individual desire rather than her submissive role. In the beginning of this play, Grania, the daughter of an Irish king is intended to be the bride of Finn. Though her father forced her to marry with foreign king, she rejects his proposal and chooses her own destiny as she says 'My father was for the King of Foreign, but I said I would take my own road' (38). Taking her own road reflects that she focuses her own desire and by rejecting her father's proposal, she is rejecting those values which are imposed by patriarchy. As Simone the Beauvoir writes in her book The Second Sex 'One is not born, but rather becomes, a woman' (319). That means woman is constructed by society, there is not any respect of women's individual desire. If someone tries to break that chain she is no more remains the traditional woman which is constructed by patriarchy rather than she reflects the image of new woman. Grania's central role in the play reflects same kinds of characteristics. It is not Grania who is running after the King of Foreign but the King of Foreign is running after her. Not only Foreign King but also Finn and another warrior Diarmuid are also running after her. When she saw Diarmuid she quickly changed her decision to marry with Finn and she wanted to marry with Diarmuid because once upon a time she was influenced by his courageous deeds. Grania's passion for Diarmuid made Finn jealous but she did not care that matter. Though there is also conflict between Grania and Diarmuid after their marriage but every time, she successfully took part in that debate. She did not remain submissive. She question marked Diarmuid's desire to marry her as she claimed it was not love that brought him to wed her but it was due to the jealousy of the King of Foreign which made him to do so. She doubts his love. Before her time, women could not doubt their husband's love because they thought they were all in all for them. Maureen Waters has written in her essay, 'Lady Gregorry's Grania: A Feminist Voice', this play is actually the rewriting of Irish tale as she says: Grania is a reworking of a well known middle - Irish tale about a young woman, betrothed to the ageing hero Finn, who falls in love with Diarmuid, his right hand man, and persuades him to run away with her. In many extant versions of this story, their passion is fated because of Diarmuid's love spot, the ball sierce, which is normally concealed from view. Obviously the ball sierce is a mark of potency as no woman can resist Diarmuid oath of loyalty to Finn, however, he and Grania live in chastity for a period of time. Finally, spurred by jealousy, he makes love to her. Finn catches up with them, causes the death of Diarmuid, and reclaims Grania. (15)

By subverting the image of Grania created in the myth; Gregory tries to create the image of new woman in her play. Waters' above lines also somehow support to prove that idea of new woman. In Gregory's play it is not Grania who is the cause of Diarmuid's death but it is due to the jealousy of Finn which is the cause of Diarmuid's death. It shows that two men are fighting for one woman. Gregory has got success to subvert the myth. When Finn came in front of Grania and Diarmuid disguised as a beggar he says:

Finn: It is what he made me say: 'Tell that young woman,' he said, 'and that youngster with her,' he said, 'that on every first night of the round moon these seven years, there used to be a round cake of bread laid upon my road. And the moon was at her strength yesterday,' he said, 'and it has failed me to find on any path that cake of bread.'(403)

It was actually Finn himself who was following them and testing whether Diarmuid had forgotten his promise or not because he knew that Diarmuid never cheated him. But it was Grania who became so angry and broke the bread in front of him again and again and said:

Grania: That is the answer to his message. Say to him that as that bread is broken and torn, so is the promise given by the man that did right in breaking it. Tell Finn, the time you meet him, it was the woman herself gave that to you, and bade you leave it in his hand as a message and as a sign! (404).

It shows that Grania is aware about her sexuality though Diarmuid is honest to Finn but Grania could not tolerate and she herself broke the bread. And she sent message that she herself had given that broken bread which reflects Grania's courage. It is also one of the evidence of new woman. Again, she herself created her own identity and said there is no woman but would be proud, and oath being broken for her sake and she was a queen of the queens of the world, that she, a travelling woman going out under the weather, can turn her back on him this day as she did in the time that is past (404). Travelling woman symbolizes that she breaks the boundary between home and outside. She creates her own identity in outside also. After she knew that that beggar was Finn then she claimed that Finn was 
that person who left her life barren because he came always between her and Diarmuid. Though it is not clearly said in the play but can simply guess that Diarmuid and Finn are homosexual because from beginning to end Diarmuid worried about Finn more than his own wife Grania. When Grania realized the fact that Diarmuid did not love her after his death she quickly decided to marry with Finn. So many times she tried to get attention from Diarmuid but in each and every moment he turned his face to Finn and said to Finn,' 'Some wrong I did you, something past forgiving. Is it to forgive me you are waiting here for me, and to tell me you are keeping no anger against me after all' (415). Diarmuid was lamenting upon his own deed but never thought about Grania.Though Grania was waiting her response so willingly but he did not care about her desire. So, instead of lamenting upon his death, Grania took strong decision to marry with Finn though he was not interested at that moment. Although he loved her so much in front of that hypocrite society, he could not take proper decision. At that moment also Grania herself forced Finn to marry her and she put the crown on her head. That action of Grania shows her bold personality. Only a new woman can do such action. She challenged all the male characters in this play, at first her father, then the King of Foreign, Finn, Diarmuid and again Finn. Her each and every word is the symbol of her reaction as she claims:

Grania: How well he kept his own promise to you! I will go to Almuin in spite of you; you will be ashamed to turn me back in the sight of the people, and they having seen your feet grown hard in following and chasing me through years. It is women are said to change, and they do not, but it is men that change and turn as often as the wheel of the moon. You filled all Ireland with your outcry wanting me, and now, when I am come into your hand, your love is rusted and worn out. It is a pity I that had two men, and three men, killing one another for me an hour ago, to be left as I am, and no one having any use for me at all!(419). Diarmuid kept his promise to Finn. He thought Finn was his best friend, master and all in all. Those kinds of relationship between Finn and Diarmuid always hurt Grania. The unity between these two men is the main cause of her suffering. That means it is the knot of patriarchy which haunted her time and again. In the absence of Finn she dared to go Almhuin.

It is her threatening against those men who are the product of same patriarchy. Whenever they like they accept women and whenever they dislike they throw. She did not tolerate use and throw tendency and revolt against it. The same Finn, who was following her time and again but when she told him to accept her at that time he, neglected her. She explained that women are blamed to change but actually they are not it is men who change their mind as the wheel of the moon. It shows she is really a revolutionary woman. Though there was great deal of laughter when she went to the door but she did not care because she was eager to make her own road map. Anyhow she wanted to break the chain; made by patriarchy. That laughter was nothing for her. For the sake of freedom, she was ready to endure any kinds of bitter reality. Her philosophy was that to get real freedom, one had to sacrifice their life. As she justifies her view:

Grania: Open the door again for me. I am no way daunted or afraid. Let them laugh their fill and welcome, and laugh you, Finn, along with them if you have a mind. And what way would it serve me, their praise and their affection to be mine? For there is not since an hour ago any sound would matter at all, or be more to me than the squeaking of bats in the rafters, or the screaming of wild geese overhead !(420)

Grania's voice of saying open the door means not only opening simply a door but it symbolizes the freedom for women. It reflects the proto-feminist movement of late nineteenth and early twentieth century. Laughter reflects the laughter of patriarchy against women's movement. Grania as a representative character of that new woman she did not care hypocrisy of patriarchy and challenged it from her every action. Her motive to marry with Finn is also somehow related to get agency that is her quest for power. Her every action and words uttered and played in the play reflects that for her nationality, nation and women are not the only property of patriarchy. Female power is also important for her-women empowerment is the main focus of her life. Women are not puppet or toy of man. She advocates women have also free will. They can also choose their own destiny of life.

\section{CONCLUSION}

For Grania, gone are the days when women cries for their lost husband and lament upon being widow. She focuses that women can also remarry if they wish. By doing marriage with Finn after the death of Diarmuid, she proves her free will and her desire for power from every sides of life. She never surrendered in front of patriarchy, though many times it compelled her to do so. It was not a joke to challenge patriarchy but she victory. It is not the victory of only Grania but it is the victory of women's movement. Individual freedom is the motto of her life and that individual freedom becomes collective freedom for all women. Grania's courage, wisdom proves that she is a new woman emerged in the New Ireland. By presenting such a revolutionary character Grania; Augusta Gregory 
proves herself as a revolutionary writer. She is also one of the representative writers of proto-feminist movement. Hence, Grania is the emergence of new woman in Augusta Gregory's play Grania.

\section{REFERENCES}

[1] Boydston, Jeanne. "The Pastoralization of Housework." Women's America: Refocusing the Past. Ed. Kerber K. Linda and De Hark Sherron Jane. New York: Oxford UP, 2004.

[2] Dumenil, Lynn. "The New Woman and the Politics of the 1920s." OAH Magazine of History 3(2007):22-26.

[3] Gregory, Lady Augusta. Selected Writings. Ed. Lucy McDiarmid. London: Penguin, 1995

[4] Leeney, Cathy."The New Woman in a New Ireland?: Grania after Naturalism," Irish University Review 34(2004):157-170.

[5] Ronsley, Joseph, "Lady Gregory's Grania." The Canadian Journal of Irish Studies 3(1977): 41-58.

[6] Waters, Maureen. "Lady Gregory's Grania: A Feminist Voice." Irish University Review 25(1995): 11-24.

[7] Waugh, Patricia. Literary Theory and Criticism. New York: Oxford UP, 2006. 